\title{
The monstrous and the grotesque: (De)scribing and unmasking eschatology in Sepedi folktales
}

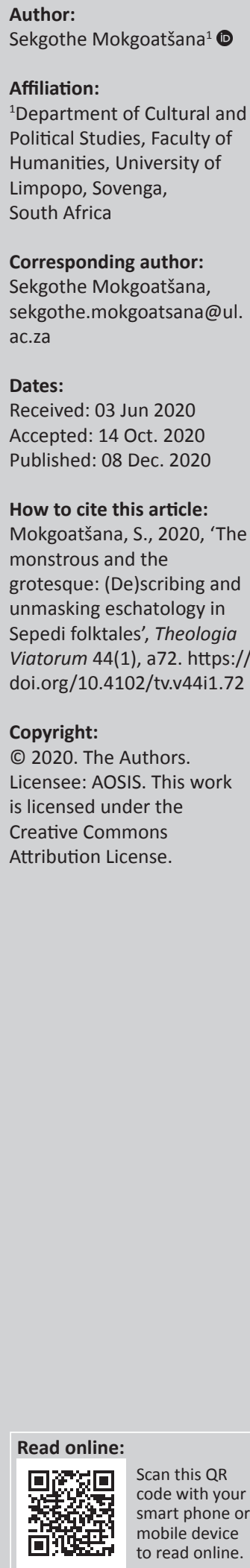

The Kgolomodumo story is becoming extinct in Sepedi folklore with the risk of losing its deep structure and embedded meaning. Very little, if any, has been performed to determine the relationship between the monsters and cosmology, also revealing how they are used to construct eschatology. In this article, I analyse the story of a monster and explain how monstrosity and the grotesque are used as a discourse to craft, uncover and (re)construct how Bapedi interprets the teleological and eschatological from the tale; Kgolomodumo. The tale is a source of explaining the metaphor of the devouring monster to describe the end of things and messianic eschatology in Sepedi religious conceptions. The story was conveniently chosen from a folklore anthology, Diphekotšabagologolo because it is a threatened textual construct. The interpretation of the tale is both Afrocentric and hermeneutical relying largely on my knowledge of Sepedi culture and folklore; drawing from my insider, self-reflexive engagement after teaching of folklore as indigenous knowledge for the past 30 years. The story is framed within the postcolonial discourse, selecting the Afrocentric lens as a tool to explain and contextualise eschatology within African religion.

Keywords: Kgolomodumo; monsters; eschatology; indigenous knowledge; myth of creation; cosmology and cosmogony; worlding; grotesque; Sepedi.

\section{Introduction}

South Africa, like the rest of the world, is populated by stories of monstrous animals which shape the mythologies of the people who produce them. Amongst the common narratives are the stories of Tokoloshe (Thokolosi) appearing predominantly amongst black communities. Thokolosi, as known in Sepedi, is a feared animal believed to be sent by witches to perform their whimsical wishes. Next is the story of impundulo, a monstrous lightning bird as known amongst the Nguni people. This is believed to be a shape-shifting creature, masquerading as a human being, or a momentous familiar that guards and protects a particular traditional healer or a witch. It is believed to have powers to summon lightning and thunderous storms. One breath-taking story is that of a gargantuan water creature called Inkanyamba. Inkanyama is sometimes described as a large water snake or an eel-like eerie creature that can control the weather. Other than these narratives are stories of Kholomodumo (Kgolomodumo) told amongst the Basotho, Bapedi and Batswana. Other queer creatures are less reported such as sefirilokwane, kokolohute (a one-legged creature), mogorompša (dog-like creature with human features), mamokebe (mamogašwa [mermaid]) madimotsele (god-like creature that abducts children), but moselapšhe (seems to be the same animal as mogoropša; probably dialectical synonyms) in Sepedi folklore.

Whilst eschatology has been studied in various religions, little has been in Sepedi to account for how the Bapedi construct their own eschatology. The narratives cited above, together with the story of Kgolomodumo are constructed to interpret the world around them. People want answers to the wonders of the world, seeking to understand reality, and to give order to the world. No society in the world holds a monopoly on its vision about the future, and what they shall become after death. Consequently, these visualisations about the end, and the hope of what life shall be after death is bound to differ from one culture to another. So, Africans in their varied ethnicities, although insignificant or small, they have a futuristic concept, especially about where their souls shall be, and what they are likely to become after their death. In their interactions with the world, they want to establish the meaning of the living organisms inhabiting the world, and imagine what the world was like before them. Most of these animals are used to explain queerness, oddity and otherness in the society that produces such animal characters. The interest of this article is in the story of Kgolomodumo, which is a trope to explain Bapedi constructions of the end and postulations about life in the hereafter. Despite that previous studies were performed on the monster Kgolomodumo as shall be seen in the literature section to follow, none of these works have 
shown the relationship between the monster and cosmology, as well as monster and eschatology. In this study, I will deal with the Kgolomodumo narrative to explain how it is used to construct an indigenous eschatology amongst the Bapedi, and illustrate how they describe their conceptions of cosmology and origins of the world. I will examine the monstrous creature chosen for this discussion and locate it within the eschatological discourse as a way of deconstructing indigenous ways of constructing knowledge about the world, and its creation. Furthermore, the Kgolomodumo narrative will be used to conjecture the possibility of a prehistoric world, a world on which later civilisations are rooted. I have conveniently chosen this narrative because it has become a dying narrative, yet abound in cosmological and mythological significance. In addition, there are insufficient oral versions available for oral transmission. I am aware of the various versions of the same tale, however, I have deliberately chosen the tale captured by Stephen Maje Serudu in Dipheko tša bagologolo (1999) because it will assist me to make my arguments on myth, eschatology and cosmology. Although the common method of collecting stories is fieldwork, I have preferred to choose written stories for the analysis in this article for reasons advanced above. The method of collecting data, therefore, is archival, and the method of analysis is Afrocentric and hermeneutical, with Sepedi culture and heritage defining the axis of the lens.

\section{Literature review}

Myths as branches of Sepedi folklore are an under-researched subject within Folklore Studies, unlike the folktale. Prof Phaka Makgamatha can be considered a leading scholar, and the first to offer a critical analysis of the folktale tradition in Sepedi. He wrote his Master of Arts on Characteristics of the Northern Sotho folktales: Their form and structure employing various narrative theories of structure to interpret the Sepedi folktale. In his doctoral thesis, The Nature of Prose Narrative in Northern Sotho: From Orality to Literacy (Makgamatha 1990), he explored the various aspects of narratology from orality to literacy. The influence of Walter Ong on literacy and Vladimir Propp on the fabula and narrative is unquestionable. In both studies, Makgamatha $(1987,1990)$ focussed squarely on the folktale, and later experimented with various structuralism theorists such as Vladimir Propp, Levi-Strauss and Harold Scheub on Sepedi folktales. His interest was largely on the trickster tale, a study followed by him and Cannonici in South Africa. We together, developed the first and only postgraduate qualification course in Folklore Studies (MA by Dissertation, MA by coursework and $\mathrm{PhD}$ ), departing from the common oral literature and traditional literature studies which regarded folklore as some kind of literature. Whilst he taught the general principles of Folklore Studies, I taught papers related to myth, ritual and folk belief. In addition, we introduced a paper that argued that folklore was the people's indigenous knowledge, as such even taught a paper that would assist students to understand folklore as an intellectual property.

Mokgoatšana (1999) used verbal expressions in Sepedi to describe the myths of beginning. In that paper, he used the water symbol to explain the conception of the underworld, the metaphorical origins from the under-waters, the cosmic pools explained in Sepedi as madibeng, sometimes as teng go sa boelwego (a world of no return. Another figuration of the primeval origins is explained in his paper The Phallic Snake: A Sepedi Creation Narrative (Mokgoatšana 1999). Furthermore, he explored the relationship between myth and ritual to determine religious conceptions amongst the Bapedi. In this paper, Mokgoatšana (1999) explains that myth represents a story of origins whilst ritual is the drama that symbolises the story of beginning. All what myths explain find expression in the dramaturgical representation epitomised in ritual.

Ùjvárá (2018:176) acknowledges the prevalence of mythological figures devouring humans dead or alive present in numerous mythological traditions. These figures sometimes appear as large water snakes, xenomorphic creatures, large terrestrial monsters, all of which are predators devouring humans and other animals in their environment. Not all monsters are predatory, but have human-like qualities. Makhov (2006) describes the motif of a sticking out tongue as an iconography potent with ambiguous semantics. It ranges from childish, puerile representation to demonic associations. In Christian iconography, the tongue represents a dangerous part of the human body which is not necessarily sinful, but needs to be restrained. For Makhov (2006), the tongue is associated with a plethora of meanings, gluttony, verbosity, the phallus, weapon, sin, fear, blasphemy to refer to a fear of the semantic associations.

It is inconceivable that a monster may swallow without sticking out its tongue to entice and aid itself in the swallowing and digestion of the victim. The stuck out tongue, Makhov (2006:58) argues, is connected with devouring absorbing. He goes on to suggest that a sinner whilst being eaten, being drawn into the womb of the devil, becomes part of the devouring maw (one should remember that hell itself was often depicted as a maw). The tongue is, therefore, the sinner who sticks out of the devil's mouth. The iconography of the tongue and the 'monster' is not always nefarious and evil, but defined in terms of the cultural context that produces it. This is consistent with Suzanne Lewis's view that the definition of a monster inevitably depends on its epistemological function (Lewis 2010:3). It shall be seen that the metaphor of the monster in Sepedi does not automatically translate into evil, devil or demonic, but explains the apocalypse in a manner parallel to the commonplace Christian demonology and eschatology.

Classifying Setswana folktales, Kganyago (2000:65) speaks of a category called supernatural adversities encompassing the Kgolomodumo monster narrative. In his explanation, the monster usually has a huge size and extraordinary strength. In his opinion, these monsters have the capacity to swallow everything, and 'they exist to be slained' (Kganyago 2000:65). The only connection between the monster and the people is the adversarial effect, with no explanations of how the tale relates to a set of beliefs. As for Makgamatha (1999:7), the 
Kgolomodumo narrative is a work of fantasy, suspending belief. Motsamayi (2019:122) describes Kgolomodumo as a mythical monster to which I subscribe too. He battles with the decolonisation of the text, whether to use it in a postcolonial sense or not, assuming Sankatana liberated his people from the colonial system. His challenge is accounting for total liberation when the people were completely in the belly of the monster and the ravages of victimisation or colonisation are not completely shed off. Motsamayi (2019) should, however, be lauded for trying to apply the postcolonial theory as a contextual liberating theory. I will, however, restrict the narrative to religion than politics in this discussion.

Interpreting the chosen monster in this discussion should be guided by Sepedi conceptions of being; ontological, teleological and cosmological. The easiest temptation is to interpret indigenous eschatology in Christian terms, especially that most writers on African religions and philosophies come from a Christian background. Lo Liyong (1986) warns John S. Mbiti about such interpretations in his essay entitled, 'Reverend, Doctor John S. Mbiti is a thief of our gods'; something that he calls the great spiritual heist; accusing Mbiti's efforts of Africanising Christianity as a 'thief of our gods'. Interpreting African religion from the prism of Christianity denies Africa of its original religious thought, subjecting indigenous religions to skewed interpretations by people who at some level condemn it as inferior to other religions. What it does is to seek validation from other religions whose ancestries may not be Africa, and their orientation is imperial, wishing to dominate the world unlike African religion which is community based, at best restricted to family.

Boer (1986) risks the temptation to be labelled one of the cultural nihilists who propagates a view begun by Mbiti that Africans have no sense of a future. He cites his visit to some village in Ghana in 1956 where some graves were 'neglected', a matter he interprets as a 'future with oblivion', a being 'no longer' (Boer 1986:199). In his opinion, the passage of time into the past becomes disconnected with the future. What writers like Boer miss is the disruption western cultures have caused on African culture and religions. The dead are usually not lumped into graveyards outside the homestead like dumping sites, but live in the compounds with the living. Their bodies are in the cowsheds used daily as sacred sites, such that the practice of cleaning graves is a phenomenon growing out of western practices of visiting graveyards. Africans do not visit graveyards,as the home and the grave site are fused into one establishment, making the dead ever-present in the lives of the living. The home is effectively a religious site, with the fireplaces as other shrines where families connect and share narratives that shape their lives.

\section{Monster constructed and defined}

I have spent a great part of my life working as a Sepedi language and culture interpreter, translator and advisor, especially as a culture expert before the High Court. I became fascinated with the stories from creation, historic imagination and rituals and how these narratives shape and direct discourse. The manner in which the people construct monsters in their daily lives has intrigued me to excavate mythological monsters and how these stories shape the people's religious views and interpretation of the world.

In my experience as a teacher, I found a form of teacher assessment that was abused by the apartheid administration to catch out some teachers with a view of charging them, for those already permanent and to deny permanent appointment to those who were greenhorns, and probationary waiting to be declared permanent. The rise of teachers' unions led to the temporary suspension of the school inspection system that used form ET 481 to assess teachers' classroom management, subject mastery, writing activities and community engagement. In the advent of democracy, these assessment tools were resuscitated with curriculum implementers sent for in-school support and monitoring. The sight of these officials was described as the return of the guerrilla. The inspectors and curriculum implementers were called guerrillas. Teachers would run like school children in fear of the 'guerrilla'. The education officials effectively were constructed as monsters to be avoided at all costs. What this experience has shown is that monsters in people's lives are the things they fear, wishing to avoid.

Explaining the notion of a monster, Weinstock (n.d.:275) uses the expression 'it takes a village to make a monster'. This allegory well explains that every community constructs its own monsters out of their 'fears, desires, anxieties and fantasies' (Weinstock s.a:275). His expression that 'no one or nothing is intrinsically or naturally monstrous' finds expression in what we fear, to the extent that we personify it to be a deadly figure that overcomes our lives.

When the Spanish army reached the Halls of Moctezuma in 1539 , there were reports that Indians 'periodically ate human beings' (Carrasco 1995:429). Carassco (op cit) goes on to suggest that these and other reports were partially based on 'act' but based also on the time honoured European interpretive framework, which since the time of Herodotus turned the inhabitants living at the edge of the known world into one kind monstrosity or another. Similarly, the Greeks described the Egyptians as monsters and marvels. In his work, Carrasco (1995) focuses on the prominence of jaws, orifices, eating gestures and the rituals of eating human beings to explain the 'underlying premises' and 'enduring arrangements of things and persons'. Carrasco (1995:433) borrows these phrases from Tambiah who uses them to define cosmology. In essence, the eating metaphors and devouring monsters are all underlying explanations of cosmologies and oddness. The matter of oddness and otherness is a subject of my other article, as a result, it will not receive fair treatment in this discussion; however, I will draw from my personal experience to demonstrate how monsters may be created. 
I will share one of my early experiences in the community when various monsters were created to ward off and admonish. One of the weirdest memories that stays with me was when Jane Furse Hospital realised that tuberculosis (TB) and poliomyelitis patients were not undergoing regular check-ups in the late 1960s and early 1970s. The tension between the hospital as the metaphor of British colonialism is well documented by Goedhals (1998, 2000; Mokgoatšana 2019). As a result of this tension, the hospital has always been treated with suspicion, such that local people would rarely consult there. They would rather revert to traditional healing system than go to the hospital. One of the myths held in the community is that admission into a hospital would give the hospital an opportunity to eliminate them with their medicine (injecting them with a deadly poison). Because of this tension, the hospital remained a monstrous institution. Although the hospital wanted to reach out to eliminate the threat of poliomyelitis which was ravaging communities by vaccinating children in the community, the effort was treated as a menacing exercise. The outreach programme was to save people who had problems in reaching the hospital because of the distance by bringing services closer to the people, and also, supporting TB patients, as well as transporting those who needed transport to the hospital for the 6 months institutionalisation. Because of these myths going around at the time, the sight of the hospital vehicles was a scare. There was a truck that delivered medical supplies to the clinic, and sedans were employed to go village to village to conduct vaccinations. These hospital officers found it very difficult to penetrate communities. The sight of these sedans sparked fear, people ran for 'safety'. There were rumours that these officers are not connected with the hospital but murderers who would entice people to receive large sums of money and a blanket to bury the unsuspecting clients, playing with their lives.

Weisntock's conception of a monster is not far removed from Clasen's (2014) thought that no one is evil in the world, as a result:

Nobody in the real world considers himself or herself evil. Evil is a psychological artefact, a 'false image' that is projected onto an antagonistic out-group or a member of an antagonistic outgroup, probably because characterising an opponent as evil tends to dissolve painful self-blame. In the perspective of social psychology, evil is a moralising and distorting concept that emerges from a psychological need to de-rationalise the behaviour of antagonistic others, attributing to them a pure and unmotivated desire to inflict suffering (p. 1).

Clasen's view explains clearly how human beings construct the other as an intruder, an offender; a disruptive self who becomes an immediate menace. What is considered evil, or a threat is outside the self, thus selfhood declared a safe space than the other. The hospital narrative discussed in the preceding paragraphs is moulded on the same premise of the hospital as an outsider, something not to be trusted. In 1919, Freud published a paper in which he characterises the 'uncanny' as that which 'arouses dread and horror...certain things which lie within the class of what is frightening' (Haberstam 1995). Can horror truly be defined in relation to terms of 'uncanniness' or 'pain of circularity'?

Writing on the relationship between horror and monster narratives, Carroll (1992) explains that the emotive response of characters to the monsters is important to note:

Within the context of the horror narrative, the monsters are identified to be impure and unclean. They are putrid or mouldering things, or they hail from oozing places, or they are made of dead or rotting flesh, or chemical waste, or are associated with vermin, disease or crawling things. They are not only lethal but they make one's skin creep. Characters regard them not only with fear but also with loathing, with a combination (sic) of terror and disgust. (p. 54)

The horror narrative arouses feelings of fear, freezing the audience's emotions, petrifying the character into a froze. Why are people interested in telling or creating horror stories with so much monstrosity? Schneider (1999) offers us a probable response following Aristotle's interpretation of tragedy:

Like tragedy, horror promotes emotional catharsis in audiences; like fantasy, it offers viewers an escape from the tedium of everyday life; like comedy, it provides a relatively safe (because relatively disguised/distorted) forum for the expression of socio-cultural fears.

This cathartic effect alluded to allow the community that produces monsters to deal with fear, anxiety and their desires. In fantasy, they attain what they wish for, the removal and destruction of the unwanted stranger or behaviour, or the total eradication of a menacing situation.

\section{Eschatology}

The concept 'eschatology' is derived from the Latinised form of Greek eskhatos 'last, furthest, uttermost, extreme, most remote' in time, space and degree (viewed 13 May 2020, from https://www.etymonline.com/word/eschatology). To understand eschatology in African culture takes into account two major issues, meaning and concept of time, as well as the presence of the afterlife. This contemplation about the end of life, and a possibility of life in the hereafter as exemplified by the return of ancestors in the world of the living is explained better by the concept of eschatology.

Aderibigbe (2020:unpaginated) begins his discussion on the term 'eschatology' by acknowledging two streams of thought on the definition; firstly, those concerned with the etymological definition, secondly, those keen on the functional value of eschatology. Etymologically, the term is traced from eschatos and logos, referring to the teachings of the last things. The very concept of the 'last things' is captured in the term eschaton. These teachings focus on the end of times, death or any other event related to the end. In respect of the functionality of the concept, reference is made of the historical issues connected with the last things. Aderibigbe 
settles with Mayimbe's definition which he quotes laboriously:

Generally speaking, eschatology is the theological doctrine of the ultimate things, of the last or final days, of the world to come, of life after death. It is a theological investigation or religious quest about the meaning of the destiny of the world and of human beings. In this sense, eschatology has a teleological dimension. It deals with expectation, with future. Its relevance lies in the belief that not everything about human beings is over after death, that death is not the human being's radical end or absolute destination and that there is something beyond.

This explanation points to 'hope', the 'future' and how these are connected with people's views about eventuality, and life after death. The original meaning of eschatology was confined to death, judgement and final destiny. Eschatology refers to the doctrine of the last things, the last days or the end of times. The idea was originally used to describe Jewish, Muslim and Christian beliefs, but has been extended by historians to use eschatology to refer to conceptions of the last things: immortality of the soul, rebirth, resurrection, migration of the soul and the end of time. Richard Landes goes on to explain for other religions, unlike in biblical religion; opines that eschatology does not necessarily refer to the end, but 'rebirth' and the 'cyclic pattern of cosmic destruction' (Richard Landes, n.d., Encyclopaedia Britannica). Consequently, Landes provides for historical and mythical eschatology. Van Wyk (2001:191) argues that eschatology does not merely pertain to the ending of time, but also to reality and the coming of the kingdom of God. He proposes three ways in which eschatological knowledge may be gleaned, namely, by speculative thought using astrology, scientific knowledge and knowledge of revelation. In African eschatology, two of Van Wyk's premises may apply. First, the stars, the firmament and the environment are used to interpret the future, as well as revelation. Most African priests and prophets' knowledge is revealed to them in their dreams and visions. All these are speculative ways to ponder over the future, and what shall be.

Flowing from Landes' words, in mythical eschatology, the origin of the world is reproduced at the end of the world, that is, the process of creating order out of chaos that occurred at the beginning of time occurs again at the end of time (Roland Landes, n.d., Encyclopaedia Britannica). At the beginning, order and natural laws are established, and followed by a decay and degeneration. This represents an eternal struggle of chaos and order, thus leading to salvation. Salvation redeems the world, and recovers the loss of order, security and sanity. The gods and spirits as well as rulers retain their seats, with things returning to the original balance of tranquillity. Mythical eschatology refers to the myth of cosmic return. Eschatology in Sepedi may take two forms; messianic and apocalyptic. The messianic focuses on a redemptive figure who saves the world from the great catastrophe whilst apocalyptic eschatology explains the destruction of the world and replacement by a righteous order. Although apocalyptic eschatology traditionally relates to the end of times, a tension between the old and the new; it also includes the revelation of mysteries. These old and new worlds are contemplated in Mbiti's notions of sasa and zamani coined from KiSwahili concepts of time (Kalumba 2005). These words help us understand the 'past', and the 'nowness'; temporal concepts which are not necessarily divorced from the future as some may argue. There is no past without the present, or even the present without the future. All these are intertwined into an interwoven knit unit, such that ancestors are not only in the past, but may appear in the future in the presence of the living. What this reveals in African thought is the centrality of immortality expressed in the cyclic nature of spirit and body. This explains the interconnectedness of the afterlife with the present, allowing the living dead to appear in the life of the living, closing the gap between the physical world and chthonic world. Chukwuelobe (2013:85) speaks of the constant interactions between the dead and the living, between spirit-land, and the human and the world'. Writing on Igbo thananology, Chukwuelobe (2013:85) foregrounds the presence of eschatology in Africa by declaring that 'for the Igbo, death does not constitute an end', rather 'intimates an authentic being which expressly embodies eschatology'.

Bowens (2019) believes eschatology is concerned with time, 'the end times or last things' (Daymond, Ware \& Williams 2019:213). He further gives an elaborate definition explaining eschatology as teachings or discourse about the last things or the end of the age, 'how God will orchestrate God's supreme and final purposes for the world and creation' (Daymond et al. 2019:221). This argument clearly points out that eschatology is connected with teleology.

The connection between myth and eschatology is so strong that oftentimes the terms are used interchangeably to mean the same thing; however, Frost (1952:75) cautions that the meanings should be treated carefully adding:

Eschatological thought I take to be a form of expectation which is characterised by finality. The eschaton is the goal of the timeprocess that after which nothing further can occur: it is the climax of teleological history. It may itself possess the characteristics of time and continuity, but it cannot even in thought be superseded by a subsequent event. Just as the child never questions what happens after the Prince and Princess marry and 'live happy ever after', and the Marxist does not contemplate the future course of events once the classless society has been attained, so the eschatong is that beyond which the faithful never.

Whilst myth is about beginning, eschatology concerns with 'finality'; 'that after which nothing further can occur'. It represents the end of things, the beginning of the end.

In this article, eschatology should be understood as a theological concept that cuts across all religions that express hope about the future, describing a vision of the end of time, the last times, how the end is envisaged. These ideas are not restricted to Christology, as Mayemba (2009:1) explains that it does not propose or require Christology, and, 'it is not an exclusively Christian category'. Mayemba (2009:1) goes 
further to suggest that eschatology does not have to be Christocentric. It cannot be disputed that eschatology is debated largely in Christian theology, however, it should be noted that the concept is a theological construct found in many world religions. I have great respect for all interpretations of eschatology in many religions; however, this article wishes to confine itself to African eschatology using Sepedi as an entry into indigenous eschatology. In this article, eschatology should be understood as a discourse amongst Bapedi to understand and interpret the end of times, the destruction of a world order and the creation of another as shall be seen with the devouring monster, and how the nation was saved from the mouth and belly of the monster. These configurations are philosophical constructions of being, and worlding, and how to be is defined and refined using cosmology and cosmogonic images. It is in the spirit of this article to locate the story of Kgolomodumo within Sepedi mythic knowledge which helps us understand indigenous constructions of epistemic thought about creation. This creation narrative allows us to penetrate a cosmic world populated by animals working as instruments to interpret noumena and phenomena as Mokgoatšana (1999:34) would describe. It is important to recognise that dismissal of African religions, and their knowledge systems has significantly marginalised how Africans interpret origins, and how they relate to that world order and its genesis. This article, therefore, is about repositioning the place of indigenous notions of eschatology amongst others, an exercise Kgari Masondo (2014:117) calls the decolonising of mythologies because the colonial encounter recognised only the colonial masters to have a mythology worth pursuing. They denied the existence of religion amongst Africans, or at best reduced to animism. To this end, Mönnig (1967) who is considered an authority on Bapedi cultural anthropology makes very worrying claims about the Bapedi:

Modimo thus seems to have little or no bearing on the daily life of the Pedi. They have no contact with him, nor he with them. He does not appear in dreams, or in any other way. ... Although he is the giver of rain, he is not prayed to, nor thanked for rain. To the Pedi, Modimo belongs to a hazy supra-natural sphere [My emphasis]. (pp. 47-48)

Such a misconception is part of a colonial mentality eradicating African thought and the existence of ancestral knowingness which can best be described from within. As an outsider, Mönnig describes the Bapedi world from a colonial slate. Consequently, he first appropriates Modimo the masculine gender characteristic of the Christian notion of God as a Father, whereas the Sepedi Modimo has an undifferentiated gender because Modimo represents all, male and female, or any gender conceivable. Sepedi language has no provision of gender articles and prefixes, but uses specific nominal and gender suffixes. In addition, the manner in which Bapedi accord respect to the Creator is misconstrued that only ancestors receive credit for the gifts of life when in effect they are messengers to the Great God. Finally, it is worth mentioning that the deliberate deletion of prefixes in anthropological literature is part of the dehumanising project by colonial scholars in Africa. In Sepedi language, pedi refers to a number, that is two (2), not any human being. Human beings and objects have particular prefixes distinguishing them. In this case, the people are called Bapedi, not baPedi, with the prefix $b a$ - (class 2 ) referring to human beings. The latter spelling is not consistent with Sepedi writing and orthography.

\section{(W)Here is African eschatology(?)}

I deliberately begin with the question 'where is African eschatology?' with its postcolonial reflection of positioning, attempting to respond with the paradoxical affirmation, [w] here is African eschatology. This question is a deliberate quest to seek intellectual space and to reposition muted discourses of previously marginalised communities, who continue to be subjected to intellectual and epistemological dominance by authoritative critiques framed from the West, with their universalist, essentialist propensity to [w]rite over, gloss over and erase bodies of knowledge produced from the colony. This article joins the debate that seeks to liberate Africans, that they be released from academic bondage, and unleashed to interact and interlocute with other voices on an equal footing, not negotiating space through the voice of the Other, but in their own terms. To do so requires that African myths should be understood as sacred texts on their own, de-scribing the teleological, locational, cosmological, epistemological, metaphysical as well as the axiological. I posit that African eschatology is a branch of learning that restores and settles the debate whether Africans have their own eschatology or not. In a book entitled African Eschatology: Igbo Perspective, Ezeoba tackles the question of eschatology in African religions, providing the Igbo experience as a linchpin to unsettle colonial misappropriations of eschatology which claim Africa is devoid of eschatology. In his foreword, he proclaims the variability of eschatology from one culture to the other (Serudu 1990:78):

Eschatology is the study of end things - death and what lies beyond. Nearly all religions tackle the topic in one way or another. Theologians debate the different concepts of death, interment rituals, funeral rituals, final judgment, and the afterlife. Traditional African religions are no exception.

It sounds simplistic to suggest that different religions have different conceptions of death and thereafter. Joăo José Reis (2003:68) strongly supports the view that African eschatology varied from one ethnic group to another. This view was adumbrated by several indigenous expressions of eschatology as expounded in Ezeoba's discussion of Igbo eschatology (Azeoba 2018), Mbiti's concept of time to explain Akamba eschatology, although the latter disputed the presence of eschatology in African religion (Bako 2009:42), claiming in African thought; there is no history moving 'forward' towards a future climax or towards an end of the world (Mayemba 2009:4).

This article takes a stand to decolonise debates in eschatology, in order to claim the voice of Africa in indigenous religions, and liberate the same from colonial hermeneutics, and the 
capture by hegemonic discourses that wish away the independence of African epistemic thought, as well as clear cosmological explications. This can best be achieved with a clear project of delinking the colonial matric from African thought. As early as 1996, Ngugi popularised the axiom that there were many centres in the world, and each culture happens to have a centre from which reality should be gleaned. Bringing this debate home to eschatology, it should be clear that every culture produces its eschatology, making it a complex task to claim a homogeneous interpretation of the concept. For this reason, this article recognises the existence of eschatology in all cultures.

In addition, it is worthwhile to challenge the essentialisation of Africanness as if all Africans are homogeneous, and have everything in common. It is for this reason that any debate of African eschatology should find expression in the myths of the people, however small the groups may be. My choice of Sepedi eschatology is part of this liberating exercise to avoid what Fanon describes as 'self-mutilation, self-repudiation and self-betrayal' (Lovesey 2015:107) when an intellectual chooses to reach compromise with the coloniser, choosing to interpret reality from the perspective of the slave master. The choice of Sepedi as a fulcrum to explain indigenous eschatology does not, however, deny the shared consciousness and mythologies prevalent amongst Africans. In this discussion, eschatology should be framed within African discourse, using Bapedi narrative as a locus of defining the problem of eschatology and interpretation. This interpretation will help us understand indigenous constructions of eschatology, and how Bapedi world view relates or differs from others in the body of African religion; I am worried to use the term African Traditional Religion because of the derogatory nature of the term traditional which suggests primitivity, underdeveloped and pre-modern. I note that it is an established and standardised concept in African Theology, despite its connotations which are not immune from western framing of Africa as a Dark Continent.

\section{Kgolomodumo: The story summarised}

This is a story of a colossal monster ever to ravage the community. It swallowed people and animals. Kgolomodumo, as the name suggests, produced a life-threatening thunderous sound that pushed people into frenzy. Shepherds and cattle minders were swallowed together with their dogs. Everyone who dared to attack the monster was swallowed as well, this happened to the regiment of men who wanted to save their children too. Everyone was swallowed. Only an old woman survived the onslaught. This woman developed a putrid boil or abscess on her thigh, from which twins were born, Mašilo and Mašape.

The two boys were warned of the danger of a roaming monster, Kgolomodumo. In their hunting expeditions, they remained cautious of their mother's warning about the menacing monster. One day Mašape headed east whilst Mašilo headed west on their hunting expedition. Whilst hunting, Mašilo met a strange creature which introduced itself as Mpepentshohlole (Carry me on your back, offload me). As the name suggests, the creature asked Mašilo to carry it, and offload it from his back. This caused frantic panic on him because it was not easy to do the two opposite actions at the same time. After several trials, he had to seek his brother's intervention. He called Mašape to bring his dogs. Mašape came with Mašilo's dogs. The creature killed all of Mašilo's dogs and only one slim and scabby dog remained. Mašape tried to hit the creature with branches, pierced it with a spear and arrow, but the creature swallowed them. It grew larger and larger, as it shouted 'Kgolomodumo', its size grew incredibly.

At the end, the scabby dog managed to kill the monster. From the belly of the monster, thousands of people and animals were saved. All accompanied Mašilo and Mašape to the village. Mašilo and Mašape were declared dikgoši (kings), and their mother's fear was turned into joy finally.

\section{The monster 'Kgolomodumo' and eschatology}

The word kgolomodumo is a compound noun derived from the adjectival, -kgolo (big, huge); and the nominal, modumo (sound). The charactonym suggests a being with a large sound, an increasing loud deafening sound. Kgolomodumo was a colossal, man-eating, shape-shifting monster to be represented in Sepedi folklore. It is described as the largest animal ever to live in their world. This swallowing monster captured and swallowed all livestock and human beings. It had an incredible capacity to swallow almost the whole village, including everything that presaged danger or malleable catastrophe. Unlike other monsters, it is purely an animal of a mammoth expanse. It was constructed to negotiate the boundaries of human life and animal life. The monster as narrated in this tale had qualities of an animal, and human properties like speech or body structure. The sight of kgolomodumo evokes emotions of horror and frantic fear. This is the fear that society wishes to oppress or suppress, yet allow it to dominate fantasy stories. In the world of fantasy, human beings create a platform on which everything is possible. When disability is not acceptable as a social norm, fantasy enables it to be legitimised. This kind of animal, imagined, real or constructed, instils fear and anxiety in the world. It is produced, and reproduced in the folktale life world where everything is possible. Characters like the Kgolomodumo are set in a world radically different from our life (Bascom 1965).

The Bapedi story of Kgolomodumo is part of a large body of African myths of swallowing monsters and 'demons'. A similar story is told amongst the Basotho in which tale, a little boy, referred in various versions as Ditaolane or Moshanyana or Moshanyana Sankatana. In the tale and its variants amongst various cognate groups, the monster is killed by the insignificant character in the community, a little boy or a 
scabby dog. In the Sepedi version, it is Mašilo's dog that finally succumbs the monster into death. Mašilo takes the credit as the owner of the dog. The hero is eventually crowned as the king of the people. Whilst Mašilo is crowned as a king, his twin-brother was equally crowned to be a king as well. In Sepedi, twins represent oddness, strange phenomena that are avoided as far as possible. It is for this reason that the weaker twin was always eliminated. In cases where elimination has not happened, one of the greatest challenges is to determine who is the eldest or youngest because that is important to determine succession. The last twin is considered the eldest, assuming seniority; with a simple explanation that in Sepedi protocol, the senior follows the lowest commoner who leads the way. Should anything happen to the commoner ahead, the leader following from behind is likely to survive the impending danger. In addition, the commoner(s) ahead of the kgoši are destined to die with him in the event of his death; one becoming letolo (one on who the knees of the kgoši would kneel in the grave) and mosamelo (a pillow on which the chief would lay his head). In principle, the kgoši is never leading from the front, but a few places behind several commoners who most probably are outsiders on which the kgoši depends for particular skills and craftsmanship such as curative medicine, defensive medicine or basically trickery of the night.

Another important matter to consider about twins is the belief that they share a common soul occupying different bodies. Because of this, in the event of one twin dying, the other twin has to enter the grave first before the dead twin gets into the grave. The practice begins from leaving the house, and the dead twin leaves the house, as the surviving returns into the house. This is going to be repeated when the corpse has to be interred into the grave. What this ritual explains is to ensure that both souls do not go into the grave together, and die. In this way, the surviving twin recovers the 'half-soul' that has deserted the deceased. What does all this have to do with the analogy of the twin in the story? The storyteller chooses to end the story with each twin getting a share of the throne, as two bodies sharing a single soul. This imaginative technique resolves a potential conflict over the bogoši (royalty).

Another important aspect of the tale is the mysterious birth of the mythical hero who kills the monster. In most narratives, the only surviving mother delivers the messianic figure who saves the nation. In the Basotho tale, the mother had just given birth to a baby boy who mysteriously grows faster than usual to go and fight the monster. In the version under discussion, 'Kgolomodumo' (Serudu 1990), the twins are born from a putrid abscess from their mother's thigh. Twins occupy a popular motif in Sepedi lore, demonstrating how the people have grappled with the challenge of twinship in their community. Twins are a puzzle because they complicate people's understanding and interpretation of their ranking order in respect of class rank, political rank and rules on succession. They pose rivalry between the two, and extreme jealousy because they are vying for the same goods and services, including position in the lineage. Unlike in real life situation where the other twin is often eliminated, the story provides for an alternative solution of a shared kingdom as a reward for killing the Kgolomodumo. How this will pan out in real life would be interesting, especially on dividing the crown.

The Kgolomodumo narrative follows a particular structure across cultures in Southern Africa:

- A colossal monster swallows up the whole village or country

- Those attempting to kill the monster are swallowed too

- A single woman survives

- The woman gives birth to a single son or twin

- One of the twins manages to kill the monster, and saves the population

- The young man is crowned the king of the people.

I want to laboriously begin with the Kgolomodumo narrative with the quote which says:

Mathomongthomong go kile gwa ba gona phoofolo ye e bitšwago Kgolomodumo. Bjale e be e re gebašemanyanabaile go diša dikgomo kua madišong, phoofolo ye e tsogela dikgomo tša bona, e di je ka moka e di metše. Bašemane ba ile ba leka go hlabana le yona gomme le bona ya ba ja. Ge bašemane ba feditšwe ke phoofolo ye, batho ba ile ba hlaba mokgoši wa thušang! Banna ba ile ba tšwa ba eya go hlabanela ba bona. Le bona ba ile ba fihla go yona ya ba metša ya ba ya metša le basadi ba bona. Go ile gwa šala fela mokgekolwana o tee (Serudu 1990:77) [My emphasis].

[In the beginning, there was an animal called Kgolomodumo. When small boys had gone to herd cattle in the veld, so this animal would attack their cattle, swallow them and eat them. The boys tried to attack it with spears, they too were swallowed. When all the boys were completely swallowed by this monster, the community shouted for help. Men came in drives to go and fight for their children. On arrival, the animal swallowed them, and in addition, swallowed their wives. Finally, there was only one old lady who survived].

The story begins with the expression 'mathomongthomong' (in the beginning), situating the story to the beginning of times, when the Creator conceived of the world. This extraordinary beginning gives the story a sense of authenticity and authority. The monstrous and grotesque creature is located in the first scenes of creation with human beings who it later swallowed together with other animals in the biosphere. I want to categorise this narrative as a myth accounting for the existence of a pre-existing world. In the introduction of Approaches to Greek Myths Edmunds (2014:1) explains [Greek] myths as retold stories about gods and heroes, and sometimes about monsters with which they have to contend with. These stories have 'special meaningfulness', Edmunds (2014:1) argues, a value, which later societies would want to draw inspiration from. Not only are myths handed down from the past, but they are the very tissue on which history is made; as a result, myth and history are, sometimes, interwoven to represent the past of a community. These narratives construct, hand down, 
mediate and negotiate particular social behaviour and modelling. This can best be seen on how the monster swallows all people, but are saved by a scabby dog. The dog metaphor is used to explain unwelcomed behaviour. Dogs are usually associated with filth, gluttony and inhumane behaviour. The image of a dog with scabies compounds the problem further to explain how society would avoid. Beyond expectation, it is such a dog that saves the world from extinction. The story awakens us to the value of the downtrodden, the poor and the commoners that they are as important as everyone in society. It is for this reason that the nation is not saved by usual heroes and heroines, but by the least expected; someone of a very low status; at best a sickly dog when strong and healthy dogs were swallowed together with the nation.

In the Kgolomodumo narrative is a mythography constructing a world other than our own. The audience is thrown into the primordial past in the world of myth where the story is authority, its content the 'truth' to be accepted without questioning. It is a story set like a creation story. By their nature, monster narratives are largely mythological. The monster's capacity to swallow the whole village or country describes the people's contemplation with the metaphysical, speculating a total destruction of the world they live in, and rebirth of a new world. The monster's capacity to swallow everything has theological relevance. It is an allegory for the near end of the world, projecting some possible destruction of the world to mark the end of the world. In addition, the power of the monster is symbolic gesticulations into the Creator's omnipresence and omniscience. It contemplates the power of the Creator and the other spirits connected with their lives, and the extent to which they can mould and remould the world. The kgolomodumo narrative, therefore, is an allegorical explanation of the apocalypse. It points to both the destruction of the world, and contemplation of a rebirth, a reawakening to a new revelation to the wrath of ancestors and the Creator. This can best be explained using Carrasco's (1995:430) interpretation of myth saying:

The creation of the world is constantly joined to the destruction of the world in the mythic narratives. These myths of creation are also myths of destruction, a form of coincidentia oppositorium, a juxtaposition of breaking and making.

Similar archetypes of the same narratives can be found in the swallowing motifs when the Whale Swallows Jonah, and the Armageddon's story in Revelations 16:6, contemplating the great battle on the mountain. The Armageddon narrative has several versions and archetypes found across cultures and religions. The mountain in this semiology is symbolic of the great battles fought there, representing the climax of these battles between the sinful and the good and vice and virtue. The Armageddon symbolisms draws from the mountain as a boundary between heaven and earth, the sky and the ground; thus epitomising the climax of conflict between two worlds, the old destroyed, and the new; emerging. This symbolic representation is presumably what the Kgolomodumo myth accounts for. In this sense, the narrative is eschatological, explaining the beginning of the end, the end of the old order and the world, and a new beginning. This is deeply explained by the beginning of a new life after the destruction of the monster. Firstly, the population that was swallowed is given a new lease of life, thus getting a second chance to live. They are first part of the old, and then reborn to be part of the saved world. This narrative, therefore, seems to contemplate a story of salvation, and life after death. The destruction of the monster (Kgolomodumo) ushers in a golden age, a new age of 'prosperity', an age without the menace of swallowing monsters. Secondly, the narrative constructs a new world order growing miraculously out of a blister on the thigh (groin). The thigh and its associations have metonymical and euphemistic sexual references to the 'groin', putatively referring to fertility rites, and conception (both literal, and metaphorical). These associations find expressions in Mokgoatšana's publications on Sepedi myth(ologie)s as found in The Phallic Snake: A Sepedi Creation Narrative (Mokgoatšana 1999), (Re)Visioning myth and ritual: Towards a (re)clamation of Sepedi Traditional Religious Conceptions (Mokgoatšana 1997b) and Dead and Yet Alive: the untold Story of Northern Sotho Mythology (Mokgoatšana 1997a). This rapture from the blister on the thigh has similar connotations with the original human beings 'erupting from the mud or the reeds' characteristic of Southern African cosmologies.

At one level, the 'monster' represents an indestructible force, an eternal force that has power to control and shape destinies of animals and plants. Mašilo tried against all odds to save his brother from the monster by piercing it with a spear, the monster would nevertheless incredibly continue to grow further and further:

Morago ga moo sa thoma go lla ka lentšu sa re: 'Kgolomodumo dumo-dumo'

Sa gola sa ya pele le pele. Ge a se hlaba ka lerumo goba mesebe, sa gola gape le gape sa re: 'Kgolomodumo dumo-dumo!' (Serudu 1990:78)

(After that it (the monster) began yelling: 'Kgolomodumo dumodumo'

[It swelled further and further. When he pierced it with his spear or arrow; it grew further and further and bellowed: 'Kgolomodumo dumo-dumo']

The incessant growth of the monster is not only described in words as in the lexemes; 'sa gola' (it grew); but by use of such expressions as 'pele le pele' (further and further) which in a literal sense creates an impression of the monster growing in a forward direction, suggesting not only expansion, but elongation too. This perpetual expansion of the monster increases the risk it poses in the environment in which it operates. At another level, the incredible rebirth, and vegetative growth of the monster as they attack it demonstrates perpetual presence, omnipresence. At the beginning, it demonstrates immortality, but this is lost at the end of the original world. The monster becomes a pliable instrument to separate two worlds, the old order and the new order. It stands between 'the now' and the 'not-yet now'. The death of the monster is necessary to give birth to the new order. Salvation without sacrifice is apparently a difficult task as evidenced by 
the manner in which the colossal, frightening monster has to sacrifice its life in the hands of a weakling in society.

Other than the kinesthetic image created by the narrator, the teller uses onomatopoeia to represent the colossal figure as (re)imagined by the echo of the idiophone 'dumo - dumo'. Interestingly, the duplication of the idiophone well expresses the towering sound; 'dumo' - a stem referring to modumo (sound). The reverberating sound of the monster destabilises the environment, weakens the victim and marks an impending end of the victim's life. This uproar instils fear and tension to the audience, and similarly to the whole community. These strategies are cleverly constructed to increase the size and threat of the monster.

This power engulfs, modifies and transgresses all laws of nature. On the other end, the same force represents the evil that should be conquered and replaced with the righteous. Eschatological claims are used to explain the existence of prehistoric animals, and what the world has become today without strange animals that populated prehistoric world. Although Sepedi folklore does not fully explain the existence of dinosaurs and other strange animals that would account as monsters if they were to appear into our lives today, it conceives of very strange animals and other species of reptilia populating such a world. It is in the beginning where the Creator who lived happily with the people wished to bestow immortality to all human beings until the message was delayed by mamotatamadi (a lizard with red and bluish colours on its head and neck), with a variant as kgetwane (a scaly lizard) which ran very quickly to deliver the unintended message of a lost paradise. The Paradise/Paradise Lost binary well articulates the Bapedi notions of the afterlife, and how it is expressed in mythological narratives.

There is a temptation to deny eschatology in African religions. In the preface and foreword in Contextualising Eschatology in African Cultural and Religious Beliefs, Aderibigbe (2020) notes this propensity when he declares,

... when it comes to indigenous religious traditions, the dynamics is viewed differently. Particularly, in the case of African traditional religions, the popular trend is either to deny it of any such concept or magnanimously trace its current existence to either Christian or Islamic influences on the religions. (Unpaginated)

In the same vein, Aderibigbe (2020) continues to condemn such scholars of traditional religions as Mbiti who, whilst recognising the presence of eschatology in African religions, restricts it to time and space, whilst others completely deny its presence, or if present considered to be vague and making contradictory claims. To deny the presence of eschatology in Sepedi is to dispute the people's myths about beginning, death and the role of ancestors in the lives of the living, and the latter's place in the council with their Creator. Ancestors in African cultures belong to a world outside the world of the living. This is where everyone wishes to go when afflicted with tribulations (Mokgoatšana 1996:110) wishing lefase pharoga ke tsene (may the world cleave for me to gain entry). An important figuration lies overshadowed in the vignette of a surviving mother who begets a child who saves the world from the belly of the monster. This representation is overlooked in the interpretation of the tale, focussing on the boy who saves the nation. Women in Sepedi cosmology are located in the beginning of life. Using the water analogy, women are part of the first beings to be created; as a consequence, they are associated with the primeval waters. It is no surprise that in the allegory of salvation, they form an integral part by first begetting a child who saves the world, but also that she is never swallowed by the monster. This analogy needs further investigation.

Problem of interpreting religions of the colonised people is how they are read and interpreted using schemata and frames of colonial masters. They are dismissed as inferior to the body of knowledge of theology and then relegated to mythology. In some instances, diffusionist theories are invoked to explain similarities with other world religions, claiming that over time with migrations, the stories migrated to the colonised. The stories of the colonised are seen as versions of world religions spreading through centuries of migrations. These anomalous interpretations also apply to eschatology and other interpretations of teleology. What has to be understood is that religions use similar semiology and iconographies to explain religious belief and rituals. All use water, fire represented by actual fire or candles, smoke and the burning of incense.

The above expression of a cleaving world suggests a gaping world that is ready to engulf those who wish to enter into the underworld. Unlike in Anglo-Saxon mythology where the motif of an open mouth suggests that the mouth of hell is propounded in Christian demonology, and the mouth of the Kgolomodumo's iconography explains the transition from the old order to the new world. Kgolomodumo did not occupy the world alone, but in company with other animals, which are not the subject of this discussion, will be published separately elsewhere.

When the young man's dog finally kills the monster, a new era is ushered in, the beginning of times, the end of times. Can we say that the messianic figure who saves the population from the consuming monster opens a way for Africa to speak of its soteriology? I want to argue that this messianic eschatology is linked with the story of salvation dependent on a messiah, often of a lesser status than it could be expected. This motif of the youngest achieving higher status is common in Sepedi narratives with Mokgatšana saving her community from famine when Mokgadi, her elder sister had failed. The same feat is achieved by Mashilwane in Mashilo and Mashilwane. Similarly, in Matsepe's Kgorong ya mošate, it is Boditsi, son of a commoner, Tshetlo; a commoner, who saves his community from ceaseless attacks by alien soldiers. This is consonant with Levi Strauss's theory of binary opposites; and Olrik's law of final position where significance falls on the youngest child, who is anointed or blessed to become a 
leader or saviour. In this manner, the lower schema assumes high position, whilst the high is downgraded. This schematic representation introduces a messianic leader who saves his or her community from the jaws of the monster. In this manner, people use narratives like this one to contemplate salvation and return. This return is best explained by the ancestors' ability to transit the world of the living - dead, and enter the world of the living, traversing the terrestrial and the chthonic as one, conjoined sphere. The living are able to do this in dreams, escaping from the world of the living to commune with the dead through visions.

\section{Conclusion}

This article discussed the story of a monster constructed to explain the story of the destruction of the first world to be created, and a genesis of a new order. The monster, unlike other monsters that are used to explain what people fear, or do not want to identify with, is used to contemplate finding answer to what the world was at the beginning, how human creatures evolved and finally how they explain the end of things, especially life and death. By contemplating an indigenous eschatology, the article opens a new debate on whether indigenous eschatology is independent of the foreign powers who may or may not have influenced the content of the tale, its transmission and (oral) archiving.

Unlike others who relegate the narrative into fantasy, the study locates it within myths created by the Bapedi to explain complex issues of teleology, soteriology and finality. It is interesting how the Kgolomodumo narrative shows similarities with Christian concepts of eschatology. Can the devouring monster be an adaptation of the biblical story of hell, or is it a story merely constructed by the people to reflect their own understanding and interrelation of the cosmos? Because Sepedi cosmology has no place for hell, it is possible that the gaping and devouring grave is represented by the swallowing monster which serves as a vehicle to transform and transfigure humanity to immortality. This immortality of course was lost when the message of the Creator was delayed and delivered late by the chameleon.

The Kgolomodumo narrative creates a prehistoric world where strange animals lived. It is here where the dinosaurs inhabited the world. The chameleon and other reptiles like crocodiles are probably relics of that strange prehistoric world to survive into our new world order.

Finally, it would be worthwhile for future research to probe into the complex vignette of a woman begetting a saviour and how that features in Sepedi, and African cosmology and knowledge formation in general. The parallels of eschatology not only between African religion and Christianity, but across several religions would reveal how connected religions are, and the extent to which the search for meaning about living and hope for a future is contemplated in the myths constructed.

\section{Acknowledgements Competing interests}

The author declares that no competing interest exists.

\section{Author's contributions}

I declare that I am the sole author of this work.

\section{Ethical consideration}

This article followed all ethical standards for research without direct contact with human or animal subjects.

\section{Funding information}

This research received no specific grant from any funding agency in the public, commercial or not-for-profit sectors.

\section{Data availability statement}

Data sharing is not applicable to this article as no new data were created or analysed in this study.

\section{Disclaimer}

The views and opinions expressed in this article are those of the author and do not necessarily reflect the official policy or position of any affiliated agency of the author.

\section{References}

Aderibigbe, I.S., 2020, Contextualizing eschatology in African cultural and religious beliefs, Routledge Taylor and Francis Group, New York, NY.

Azeoba, A.N., 2018, African Eschatology: Igbo perspective, CreateSpace Publishing, s.l. Bako, N., 2009, Eschatology in African folk religion, Doctor of Theology, UNISA, Pretoria.

Bascom, W., 1965, 'The forms of folklore: Prose narratives', Journal of American Folklore 78(307) (January-March), 3-20. https://doi.org/10.2307/538099

Boer, H.R., 1986, 'Time as an aspect of traditional African eschatology', Reformed Review: Prof M Eugene Ostarhaven; A Tribute 39(3), 199-205.

Bowens, L.M., 2019, 'God and time: Exploring black notions of prophetic and apocalyptic eschatology', in A.M. Daymond, F.L. Ware \& E.L. Williams (eds.), T \& T Clark handbook of African American eschatology, pp. 213-224, T \& T Clark, London.

Carrasco, D., 1995, 'Cosmic jaws: We eat the Gods and the Gods eat us', Journal of the American Academy of Religion 63(3), 429-463. https://doi.org/10.1093/jaarel/ LXIII.3.429

Carroll, M.P., 1992, 'Folklore and psychoanalysis: The swallowing monster and openbrains allomotifs in plains indian mythology', Ethos 20(3) 289-303. https://doi. org/10.1525/eth.1992.20.3.02a00020

Chukwuelobe, M.C., 2014, 'Thanatology: The Igbo/African metaphysics sense and value of death', Open Journal of Philosophy 4(1), 85-89. https://doi.org/10.4236/ ojpp.2014.41012

Clasen, M., 2014, 'Evil monsters in horror fiction: An evolutionary perspective on form and function in Parker and Pennington', in S. Parker \& J. Pennington (eds.), A history of evil in popular culture: What Hannibal Lecter, Stephen King and Vampires reveal about America, Vol. 2, pp. 39-47, ABC-CLIO/Praeger, Barbara, CA.

Daymond, M., Ware, F.L. \& Williams, E.L., 2019, T\&T Clark handbook of African American theology, T \& T Clark, London.

Edmunds, L., 2014, Approaches to Greek myths, John Hopkins University Press, Baltimore, MD.

Frost, S.B., 1952, 'Eschatology and myth', VetusTestamentum 2(Fasc. 1), 70-80. https://doi.org/10.1163/156853352X00066

Goedhals, M., 1998, 'Imperialism, mission, and conversion: Manche Masemola of Sekhukhuneland', in A. Chandler (ed.), Terrible alternative: Christian Martyrdom in the 20th Century, Continuum International Publishing Group.

Goedhals, M., 2000, 'Colonialism, culture, christianity and the struggle for selfhood: Manche Masemola of Sekhukhuneland, c.1913-1928', Alternation 7(2), 99-112.

Haberstam, J., 1995, Skin Shows: Gothic Horror and Technology of Monsters, Duke University Pres, Durham. 
Kalumba, K.M., 2005, 'A new analysis of Mbiti's "The concept of time"', Philosophia Africana 8(1), 11. https://doi.org/10.5840/philafricana20058111

Kganyago, M.P., 2000, 'The structure and style of Setswana Folktales', Unpublished Mini - Dissertation, Vista University.

Kgari-Masondo, C.M., 2014, 'Sotho-Tswana mythic animals: Stratagem for environmental conservation', New Comtree 71(10), 114-135.

Landes, R., n.d., 'Eschatology', in Encyclopaedia Britanicca, viewed 13 May 2020, from https://www.britannica.com/topic/eschatology.

Lewis, S., 2010, 'Encounters with monsters at the end of time: Some early medieval visualizations of apocalyptic eschatology', Different Visions 2(June), 1-76.

Lo Liyong, T., 1986, 'Reverend, Doctor John S. Mbiti is a thief of our Gods', in K.H Petersen (ed.), Criticism and ideology: Second African writers' Conference, Seminar Proceedings No 20, Scandinavian Institute of African Studies, NordiskaAfrikainstitutet, Stockholm

Lovesey, O., 2015, The postcolonial intellectual: Ngugi waThiongó in context, Routledge, London.

Makgamatha, M.P., 1987, 'Characteristics of the Northern Sotho folktale: Their form and structure', Unpublished MA dissertation, University of South Africa, Pretoria.

Makgamatha, M.P., 1990, 'The nature of prose narrative in Northern Sotho: From orality to literacy', Unpublished DLitt et Phil thesis, University of South Africa, Pretoria.

Makgamatha, M.P., 1999, 'Narration as art in Northern Sotho: Fro oral to written', in R. Finlayson (ed.), African mosaic: Festschrift for J.A. Louw, University of South Africa, Pretoria.

Makhov, A.E., 2006, 'The devil's naked tongue as an iconographical motif', Medieval Demonology Medium Krems 53, 44-73.

Mayemba, B., 2009, The notion of eschatology in African ancestral religions: $A$ category of deliverance, promise and rembrance, Theology Dept., Boston College, Chestnut Hill, MA.
Mokgoatšana, S., 1997a, 'Dead and yet alive: The untold story of Northern Sotho mythology', Journal of Southern African for Folklore Studies 8(1), 13-19.

Mokgoatšana, S., 1997b, '(Re)visioning myth and ritual: Towards a (re)clamation of sepedi traditional religious conceptions', Journal of Southern African for Folklore Studies 8(2), 18-26.

Mokgoatšana, S., 1999, 'The phallic snake: A sepedi creation narrative', South African Journal of African Languages 19(3), 155-158. https://doi.org/10.1080/02572117. 1999.10587392

Mokgoatšana, S., 2019, 'Of Prophesies, mythmaking and martyrdom in Manche Masemola narrative: I will be baptised in my blood', Studia Historiae Ecclesticae 45(2), 18

Mokgoatšana, S.N.C., 1996, 'Some aspects of N.S. Puleng's poetry', unpublished MA dissertation, UNISA, Pretoria.

Mönnig, H.O., 1967, The Pedi, JL Van Schaik, Pretoria.

Motsamayi, M.F., 2019, “'Sotho-Tswana” Difalavessels in selected South African museums: Challenges in descriptions and catalogues', Thesis in partial fulfilment for PhD (Art History), University of KwaZulu - Natal, Pietermaritzburg.

Reis, J.J., 2003, Death is a festival: Funeral rites and rebellion in nineteenth-century Brazil, The University of North Carolina Press, Chapel Hill and London.

Schneider, S., 1999, 'Monsters as (Uncanny) metaphors: Freud, Lakoff, and the representation of monstrosity in cinematic horror', Other Voices: The e-Journal of Cultural Criticism 1(3).

Serudu, S.M., 1990, Dipheko tša Bagologolo: Dingwalotšhaba tša Sesotho sa Lebowa, Kagiso Publishers, Cape Town.

Ùjvárá, E., 2018, 'The iconographic image of the hell-mouth, the man-eating beast and Giger's alien figure', in A. Kérchy (ed.), Posthumanism in fantastic fiction, pp. 173-192, AMERICANA eBooks (237 pp.), Szeged.

Van Wyk, J.H., 2001, 'John Calvin and the Kingdom of God and eschatology', In die Skriflig/In Luce Verbi 35(2), 191-206. https://doi.org/10.4102/ids.v35i2.555

Weinstock., n.d., Invisible monsters: Vision, horror, and contemporary culture, Ashgate Research Companion, Routledge. 